\title{
Trade Sales Promotion Strategies and Marketing Performance in the Soft Drink Industries in Nigeria
}

\author{
B. Nwielaghi Michael ${ }^{1} \&$ E. Ogwo ${ }^{2}$ \\ ${ }^{1}$ Department of Marketing, University of Port-Harcourt, Choba, Port-Harcourt, Rivers-State, Nigeria \\ ${ }^{2}$ Marketing Department, Abia state University, Uturu, Abia state, Nigeria \\ Correspondence: B. Nwielaghi Michael, Department of Marketing, University of Port-Harcourt, Choba, \\ Port-Harcourt, Rivers-State, Nigeria. E-mail: nwielaghibm@yahoo.com
}

Received: April 19, 2013

Accepted: May 8, 2013 Online Published: May 28, 2013

doi:10.5539/ijms.v5n4p96

URL: http://dx.doi.org/10.5539/ijms.v5n4p96

\begin{abstract}
Rapid changes in technology, over production, shortened product life cycles, increased competition owing to reduced barriers to domestic and international trade, mass communication and globalization have all contributed to the need for a firm to have distinctive capabilities; which create a competitive advantage over others. We are inclined to believe that fully utilized, competent and well-articulated trade sales promotion strategies constitute a competitive advantage. With the notion that trade sales promotion strategies positively correlates with marketing performance, firms view trade sales promotion strategy incompetence with grave concern. The effect of poor trade promotion strategy performance is not limited to firms alone since organizations can and do experience sub-optimal or out-right poor performance; but also to the economy as a whole. The aggregate business performance of a country's economic unit shapes its economy, since a nation's wealth is measured mostly in terms of its GDP. Among the factors critical to business profitability; fresh concerns about the efficacy of trade promotion strategies is sparsely researched. This informs the research interest in this regard, recognizing the unique role of trade sales promotion strategies that distinguishes it from other marketing communication methods, and its critical roles in pushing and creating traffic for the manufacturer's product. With a survey research design, a regression model was formulated to incorporate eleven hypotheses of interests. Quantitative data were collected through a 5-point Likert-type scale questionnaire. A total of 234 copies of questionnaire were completed by senior promotion and sales executives of two major soft drink manufacturing firms and their accredited distributors in Nigeria. We adopted Pearson's ' $r$ ' and stepwise regression with its constituents-ANOVA and T-test to determine the trade sales promotion activities that actually influence marketing performance activities in these firms. Two of the hypothesized trade sales promotion strategies were retained and adjudged relevant in determining marketing performance levels. Our findings reveal that Trade promotion strategies affect marketing performance through the use of trade allowances and trade contests. Notwithstanding this fact, the study notes that the firms are not at their optimal levels in both their trade promotion strategies and marketing performance. We therefore recommend that for optimal levels to be achieved, they should adopt trade promotion strategies that emphasize trade allowances and trade contests.
\end{abstract}

Keywords: trade sales promotion, push strategy, marketing performance, regression model

\section{Introduction}

The warm climate in Nigeria is compatible with cool drink consumption, but with soft drinks per capita consumption of just a little under thirty five liters there is considerable untapped potentials. Soft drinks also make up the bulk of commercial beverage in the country and now account for around 6.5 of every 10 liters of beverages traded up from 5.5 liters ten years ago (Corbett, 2009). Also, some investments are helping to facilitate future carbonate expansions in the country (www.prosharen.com) accessed 20 June, 2011. This has led to competition between major industry actors like Nigerian Bottling and 7-Up Bottling Companies and other local players.

Therefore in such a competitive business environment, organizations need to constantly stimulate sales through adoption of incentive marketing techniques (Chevron, 1998); particularly those directed at channel members (Narasimhan, 1990). These include trade contests, Trade fairs and Trade allowances; which when properly applied can lead to marketing performance in terms of sales turnover, market share and profitability; and other 
marketing objectives (Buyline Report, 2008; Jackson, et al., 1995; Narasimhan, 1989) however, to achieve this, firms must operate within the boundaries of core competences of its strategies (Prahad and Hamel, 1990); and within an understanding of the firm's environment which can change over time (Uzor, 2011)

Therefore, rapid changes in technology, shortened product life cycles, increased competitions owing to reduced barriers to international trade and globalization (Ohmae, 1985) have all contributed to the need for a firm to have distinctive capabilities or core-competences; which when successfully applied to firms markets become competitive advantages (Kay, 1983). In this study, we are inclined to believe that "competent and well-articulated trade promotion strategies" constitute a competitive advantage to soft drink firms in particular and firms in general. This is hinged on the premise that firms which have built up knowledge and expertise in different promotion strategies are likely to adapt to the dynamics of the marketing environment and exhibit superior marketing performance.

However, many a time, most organizations do not achieve the level of marketing performance that will yield rents for them, hence some organizations experience sub-optimal or even out-right poor marketing performance. As a result, firms get worried about the contributions of their promotion strategies to marketing performance not with-standing the large budgets used to maintain it sometimes. Thus with the notion that trade sales promotion strategies positively correlates with marketing performance, organizations view incompetent trade promotion strategies with serious concerns. Besides, the aggregate business performance of a country's economic units made by the firms shapes its entire economy since a nation's wealth is measured mostly in terms of its GDP. Therefore, if the society depends on the marketing performance of business organizations for its living standards as defined by GDP, and these organizations, in turn, depend on the competence of its trade promotion strategies to achieve competitive advantage, it stands to reason then that incompetent or sub-standard trade promotion strategies will affect the organization's marketing performance in particular and the human society's economic well being in general. It becomes apparent that the effect of poor trade promotion strategies is not limited to firms alone but also to the economy by extension. This equally explains why several studies have been conducted in these areas (Ayatunji, et al., 2009; Keon and Raju, 1991; Adebisi and Bayode, 2011). In-spite of these and other works, fresh concerns regarding the efficacy of trade sales promotion strategies remain sparsely researched. And scholars and experts have been wondering whether sales promotion and indeed trade sales promotion still serves its purpose (Ikem, 2011). This is symptomatic of poor marketing performance and a threat that should attract enquiry. In view of this we propose an empirical investigation in to what we refer to as "Trade sales promotion strategies and marketing Performance in the soft drink industries in Nigeria.

\subsection{Objectives of the Study}

1) Evaluate the extent to which trade contest affects marketing performance.

2) Ascertain the extent to which participation in trade fair affects marketing performance.

3) Determine the extent to which offering a trade allowance affects marketing performance.

4) Examine the extent to which the size of the firm affects the influence of trade sales promotion strategies on marketing performance.

5) Assess the extent to which the age of the firm affects the influence of trade sales promotion strategies on marketing performance.

\subsection{Research Questions}

i. To what extent does the way soft drink firms in Nigeria, carry out trade contest affect marketing performance?

ii. To what extent does the way these firms organize/participate in trade fair affect marketing performance?

iii. To what extent does the way they offer a trade allowance affect marketing performance?

iv. To what extent does the size of the firm affect the influence of trade sales promotion strategies on marketing performance?

v. To what extent does the age of the firm affect the influence of trade sales promotion strategies on marketing performance?

\subsection{Research Hypotheses}

$\mathrm{Ho}_{1}$ : There is no significant relationship between trade contest and sales turnover.

$\mathrm{Ho}_{2}$ : There is no significant relationship between trade contest and market share. 
$\mathrm{Ho}_{3}$ : There is no significant association between trade contest and profitability.

$\mathrm{Ho}_{4}$ : There is no significant relationship between trade fair and sales turnover.

$\mathrm{Ho}_{5}$ : There is no significant association between trade fair and market share.

$\mathrm{Ho}_{6}$ : There is no significant relationship between trade fair and profitability.

$\mathrm{Ho}_{7}$ : There is no significant association between trade allowance and sales turnover.

$\mathrm{Ho}_{8}$ : There is no significant relationship between trade allowance and market share.

$\mathrm{Ho}_{9}$ : There is no significant association between trade allowance and profitability.

$\mathrm{Ho}_{10}$ : Size of the firm does not significantly moderate the effect of trade sales promotion strategies on marketing performance.

$\mathrm{Ho}_{11}$ : Age of the firm does not significantly moderate the effect of trade sales promotion strategies on marketing performance.

\subsection{Study Variables and Conceptual Model}

From the foregoing, three study variables are extracted from the formulated research problem. These are (i) Trade Sales Promotion Strategies (TSPS) - the independent or predictor variable (IV or PV); (ii)Marketing Performance (MP) - the dependent or criterion variable (DV or CV), and (iii) Organizational factors (OF)-age of the firm and size of the firm

To fully explain the relationships and dimensions among the variables, a conceptual framework can be demonstrated below:

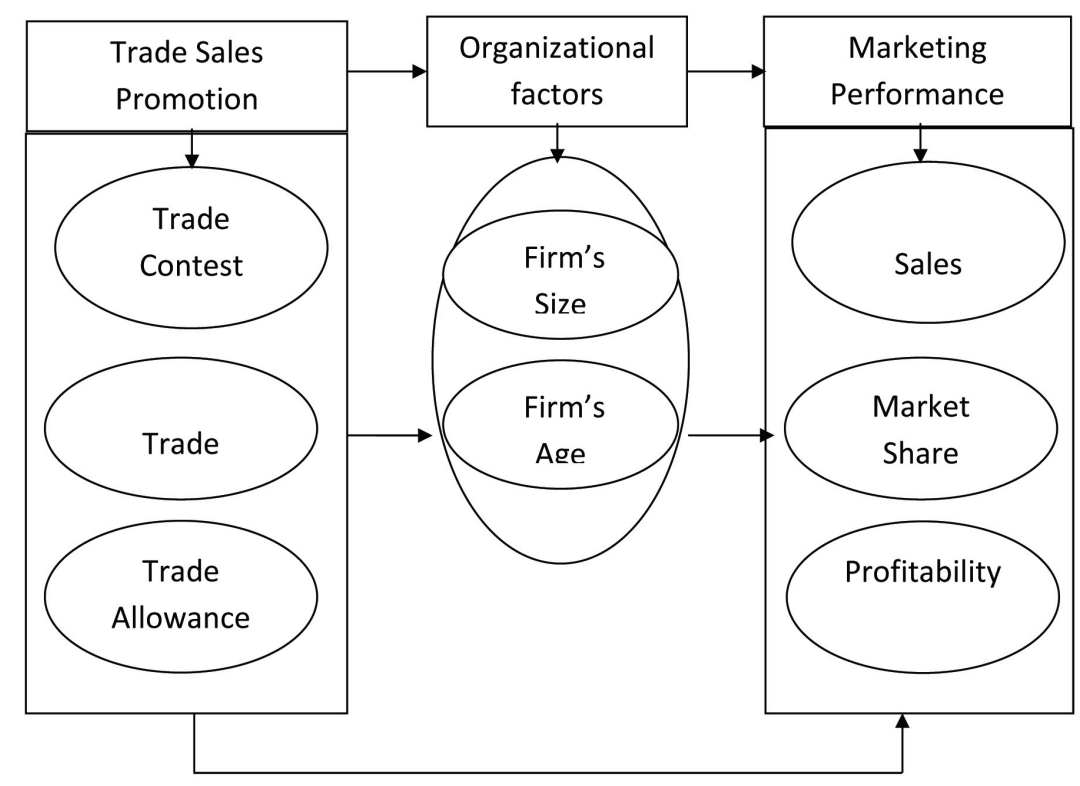

Figure 1. The conceptual model of trade sales promotion strategies and marketing performance

Source: Literature Survey (2013)

Where TSPS: Trade Sales Promotion Strategies; TC: Trade Contest; OF: Organizational factors; MP: Marketing Performance; ST: Sales Turnover; MS: Market Share; TF: Trade Fair; TA: Trade Allowance; P: Profitability.

\section{Literature Review}

Blattberg and Levin (1987) define trade promotion as "special incentives offered by manufacturers to their distribution channel members". According to Nwielaghi, (2013), "it is an aspect of sales promotion which creates incentives for channel members to share with consumers and create sales for manufacturer's merchandise.'It is also called 'Dealer' or 'trade promotion 'or 'push strategy' Push implies a forward thrust of effort whereby a manufacturer directs personal selling, trade advertising, and trade-oriented sales promotion to wholesalers and retailers. The essence is to encourage these channel members to stock the product, provide 
strategic shelve space for it and encourage consumers to buy from their outlets. For purposes of this work these incentives include, trade contest, trade fair and trade allowance.

\subsection{Trade Contest}

According to Murphy and Dacin (1998); "trade contest is an important tool to motivate sales people to achieve goals that surpass those associated with normal compensation" while Beltramini and Kenneth (1998) argued that "contest enhances overall job satisfaction" it also increases corporate profit (Wildt, et al., 1987) and can be very successful (Eisenberger and Cameron, 1999). Contest is generally used to support the brands sales force performance; because effective selling and sales management are often critical to marketing success (Avlonitis and Panagopoulous, 2006; Defloor, et al., 2006; Zeb-Obipi, 2007; Dixon, et al., 2003; Jolson, 1999; Kelly, 1973). Trade contests could be directed to regional sales managers, generality of staff, agents and brokers, accredited dealers or retailers. From the foregoing we state our first research question: To what extent does the way soft drink companies conduct their trade contest affect marketing performance?

\subsection{Trade Fair}

Is an encapsulated market place that enables the trade show exhibitor accomplish both selling and non selling functions, servicing present customers, identifying prospects, introducing new and modified products, gathering information about competitor's new products, taking product orders and enhancing the company's image (Kerin and Cron, 1987). An estimated 4,800 trade shows were conducted in the United States and Canada with 1.3million companies and 140million attendees (Buss, 1996; CEIR, 2001; Hansen, 1996). Trade shows are even greater in Europe than in North America (Gopalikrishna et al., 1995) with an approximately 13percent of marketing communications budget allocated to trade shows (Miller, 1996; Trade show Bureau, 1994); and companies annually spend more than $\$ 15$ billion and generates more than $\$ 70$ billion in sales annually from trade show exhibiting in US alone. In Nigeria total expenditures on trade shows rank third with only advertising and sales promotion receiving greater funding (Martyka, 1999). Previous scholars investigated company success based on performance during the trade shows (Gopalakrishna and William, 1992); as well as company success based on activities that took place after the trade show event (Blythe, 1999; Bonoma, 1983). There is yet an additional dimension when trade show is used to provide a future benefit to the company (RTIS) or Return on Trade Show Investment (Betis-Outland, et al., 2012) which provide both tangible and intangible benefits that accrue to the organization by trade show participants. Thus we pose our second research question-To what extent does the way soft drink firms organize/participate in trade fair affect their marketing performance?

\subsection{Trade Allowance}

Trade allowance strategy is used by manufacturers to reward wholesalers and retailers for performing activities in support of the manufacturer's brand (Lall and Kopp, 1990). Also called trade deals, it encourages retailers to stock, discount the brand's price to consumers, feature it in advertising, or provide special display or other point-of-purchase support (Curhan and Kopp, 1988). Manufacturers can use it to compensate retailers for real costs of taking a new Stock-Keeping Unit (Hoyt, 1997; Cannon and Bloom, 1991); increase forward buying (Hoyt, 1996; Aslop, 1986); identify growth opportunities (Nielsen, 1992); target consumers, implement strategy, evaluate results, and plan merchandise, (Nielsen, 1992:119). It is equally used to provide customized promotional and advertising activities to retailers (Largo, 1990; Greysen and Young, 1983); pay for all or some of the advertising costs undertaken by the reseller (Duta, et al., 1995). The retailer can also support the manufacturer through Vendor Support Programs 'VSPs' (Crimmins, 1985). However, they are often not passed on to consumers (Hoyt, 1997); and may induce the trade to stock-pile a product in order to take advantage of the temporary price reductions, which usually shifts business from the future to the present (Buzzeli, et al., 1990; sellers, 1992); retailers could resist Everyday Low Pricing (EDLP) program by manufacturers (Manning, 1994) and the retailer never spends advertising accruals (Everett, 1987; Blakkhan, 1983) and could be diverted (Berry, 1992; Hoyt, 1996) while a vast majority of retailers think that trade promotions should serve to increase sales and profits of entire product categories without concern for whether a manufacturer's specific brand benefits from the trade promotion (Hoyt, 1997). Fortunately for the trade, these abuses are being checked (Abraham and Lodish, 1990; Neff, 1995) The major types of trade allowances are slotting allowance (Hoyt, 1997; Cannon and Bloom, 1991; Liessie, 1990; Benezra, 1995; Wilkie, et al., 2002; Ante, 1989; Tienowitz, 1999; Bloom, et al., 2000); bill-back allowances, exit fees, drop-ship allowance, co-operative advertising (Elkin, 1999; Rigg, 1990) etc.

\subsection{Objectives of Trade Sales Promotion}

Manufacturers have various reasons for using trade-oriented sales promotion strategies: to introduce new or revised products; to increase distribution of new packages or sizes; to build retail inventories; to maintain or 
increase the manufacturers share of shelf space; to obtain displays outside normal shelf locations; to reduce excess inventories and increase turnover; to achieve product features in retailers advertisement; to counter competitive activity; and to sell as much as possible to final consumers (Narasimhan, 1989). The aim is to realize economic rents in form of optimal marketing performance for the firm.

\subsection{Marketing Performance}

Organizations measure the effectiveness of its trades sales promotion strategies in order to be able to ascertain the activities that are successful through performance evaluations- product market performance, market share, sales turnover etc (Richard, 2009); accomplishment of a given task (Robson, 2005); optimal goals of the organization (Bell, 2000); contribution to goals and objectives (Johnston and Marshall, 2003; Dalrymple, et al., 2004; Churchill and Peters, 1998; Fenwick and Amine, 1979) and specifically through marketing performance (Jackson, et al., 1995); return on equities and return on investments (Jain, 1997); profit, sales, market share and cash flows (Bonoma, 1989); financial measures such as sales metrics (Clark, 2000; Kokkinaki and Ambler, 1999). However, this study will rely on the financial measures of sales turnover, market share and profitability:

\subsubsection{Sales Turnover}

Also described as sales volume by many authors, it is said to be increased almost always during the period of a coupon offering or price-off deal; and consumers are highly responsive to deals, especially when they are advertised (Bemmaor and Mouchoux, 1991). It is also viewed as a marketing performance measure which shows the rapidity with which sales are procured through trade sales promotion strategies (Nwielaghi, 2003). Sales turnover is guided by the generalization that a promotion will result in temporary price reductions that can substantially increase sales

\subsubsection{Market Share}

Is an indicator of market competitiveness showing how well a firm is doing against its competitors (Armstrong and Gerene, 2007; Rumelt, et al., 1981); or the breaking up of market size in percentage terms, to help identify the top players, the middle and 'minnows' of the market place based on the volume of business conducted (Mahajan, and Muller, 1997); or the ability of business performance management in assessing the extent to which consumers patronize a given product in the market environment, (Nwielaghi, 2013). However, a major assumption regarding market share as a measure of marketing performance is that higher market share brands are less deal elastic.

\subsubsection{Profitability}

Is defined by the economist as total revenue less all cost (implicit and explicit); the latter including normal profit to the management (Mcconnel, and Bruce, 1990; Armstrong and Callopy, 1996) And without profitability, the business cannot survive at least in the long run (Hofstrand, 2007). This is why measuring past, present and future profitability is important to the firm. Also, for a particular trade sales promotion strategy to be profitable, the increase in profits due to the promotion must exceed the profits that would have occurred had the promotional offer not been made. Here we are not considering whether the promotion will make money at all; we are considering whether the promotion will make more money than not having the promotion. The simple logic regarding profitability and trade sales promotion is that putting a brand on deal is unprofitable if the market is composed of either promotion-insensitive consumers or stock-piling loyalists.

\section{Methodology}

Is a vital process of carrying out empirical studies. It forms the background in which the procedures employed in carrying out a research are designed. The methodology will be considered in this study under; research design, population/sample determination, data collection methods and data analysis.

\subsection{Research Design}

This study adopted a survey approach because it is a popular and faster technique. This approach is efficient, economical and time saving than experimental procedures. It was also used because organizations are made up of human beings whose behavior is subject to change that cannot be controlled 100percent. The overall aim was to reveal how the independent variables: trade contest, trade fair and trade allowance predict the behavior of the dependent variables: sales turnover, market share and profitability.

\subsection{Population/Sampling Method}

Is the study of a fragment of the entire population when it is not feasible to carry out the study on the entire population. The study is based on two major manufacturing firms NBC and 7-Up bottling Companies and their accredited distributors in three zones of Abuja, Lagos and Port-Harcourt. Promotion related staff, marketing, 
personnel and production staff of the manufacturing firms constituted the key informants. A key informant is a person who is well informed about the phenomena of interest in the study (Huber and Power, 1985). The study employed a systematic sampling procedure where every member of the population was given a known chance to be selected. An initial contact with the firms based on the information provided by the two manufacturing firms produced 261,680 accredited distributors.

\subsection{Determination of Sample Size}

Taro-Yamen's formula was used to determine the sample size from the population of the study in 3.2 above:

$\mathrm{n}=\mathrm{N} / 1+\mathrm{N}(\mathrm{e} 2)$; where, $\mathrm{n}=$ sample size; $\mathrm{e}=$ level of significance

$\mathrm{N}=$ population. But $\mathrm{e}=0.05 ; \mathrm{N}=261,680$; substituting the values; $\mathrm{n}=400$

Allocation to the respective regions was based on the formula by Nnabuife (2004) and applied by Amue (2009): $\mathrm{nh}=\mathrm{nNh} / \mathrm{N}$; where $\mathrm{nh}=$ no. of units allocated to each regions; $\mathrm{Nh}=$ no of accredited distributors and $\mathrm{N}=$ population of the study.

Substituting the values; $\mathrm{nh}=\mathrm{Abuja}=43 ; \mathrm{Lagos}=326$ and Port-Harcourt $=31$

\subsection{Data Collection}

This research work is purely quantitative in nature and data were collected via primary and secondary sources. The primary data came through sample of the study extracted from 3.3 above using both closed and open ended questions. And as prescribed by Huber and Power, (1985) to increase the quality of responses from key informants, we guaranteed them anonymity and confidentiality in the analysis and reportage of the results. Secondary data were sourced from financial/sales, other research reports, books, periodicals and past research works. The data were analyzed based on rigorous data treatment techniques involving inferential statistics.

\subsection{Model Specification}

The following equations were also formulated in accordance with the specific objectives and research questions and hypotheses:

$$
M P=f(T S P)
$$

Rewriting equation 1a above is explicitly;

$$
\begin{array}{r}
M P=\alpha_{o}+\alpha_{l} T P+U_{l} \\
S T O=f(T C, T F, T A)
\end{array}
$$

Rewriting equation $2 \mathrm{a}$ above is explicitly;

$$
\begin{gathered}
S T O=\beta_{o}+\beta_{1} T C+\beta_{2} T F+\beta_{3} T A+U_{I} \\
M S=f(T C, T F, T A)
\end{gathered}
$$

Rewriting equation 3a above;

$$
\begin{gathered}
M S=\mu_{o}+\mu_{1} T C+\mu_{2} T F+\mu_{3} T A+U_{I} \\
P R=f(T C, T F, T A)
\end{gathered}
$$

Rewriting equation 4a above;

$$
\operatorname{Pr}={ }_{0}+{ }_{1} T C+{ }_{2} T F+{ }_{3} T A+U_{1}
$$

Where:

$\mathrm{TSP}=$ Trade Sales Promotion

$\mathrm{MP}=$ Marketing Performance; $\mathrm{STO}=$ Sales Turnover; $\mathrm{MS}=$ Market Share;

$\mathrm{Pr}=$ Profitability; $\mathrm{TC}=$ Trade Contest; $\mathrm{TF}=$ Trade Fair; $\mathrm{TA}=$ Trade Allowance and;

$\alpha_{0}, \beta_{0}, \mu_{0}, \quad{ }_{0}=$ Intercept

$\alpha_{1}, \beta_{1}-\beta_{3}, \mu_{1-} \mu_{\mathrm{o}}$, and ${ }_{3}=$ Regression Coefficients

a'Priori Expectation

$\alpha_{1}>0$,

$\beta_{1}>0, \quad \beta_{2}>0, \quad \beta_{3}>0$, 


$$
\begin{array}{lll}
\mu_{1}>0, & \mu_{2}>0, & \mu_{\mathrm{o}}>0, \\
1>0, & { }_{2}>0, &
\end{array}
$$

In attempt to look for a better way of explaining the relationship between the variables, the linear models above were specified and found to adequately explain the objectives of the study.

\section{Data Presentation, Analyses and Interpretation}

This study uses the parametric inferential statistics to aid analyses. It investigates the opinions of major manufacturers of soft drinks (Nigeria Bottling Company and 7-Up Bottling Company) and their accredited distributors operating in Abuja, Lagos and Port-Harcourt metropolis. However, these opinions were used to measure how trade contests, trade fairs, and trade allowances explain and/or predict sales turn-over, market share and profitability.

\subsection{Regression Analysis}

Also called the test of model utility; in most surveys where regression analysis is employed, it is required that the usefulness or utility of the overall regression model, that is the regression relationship between criterion variable and predictor variables be established before testing the level of significance of the individual hypothesis (Ogon, 2007). Therefore we examine the effects of these explanatory variables on the criterion variable using the regression analysis (the ordinary least squares methods). Multiple impacts were determined using the coefficient of Determination $\left(\mathrm{R}^{2}\right)$ which looks at the percentage variation in the criterion variable as a result of variations in the explanatory variables. The individual impact each predictor in a multiple model had on the dependent variable was determined using the student's t-test (test of significance) T-test is used to find out the significance of the regression relationship. The F-ratio test allows us to test the null hypotheses that the multiple correlation is zero in the population from which the sample (which should be random) was taken. The result of the overall F-statistic as produced by SPSS version 17 is:

Table 1. The effects of trade promotion on marketing performance

\begin{tabular}{llllllllll}
\hline Variables & Coef. & t-cal & $\begin{array}{l}\text { t-tab } \\
(0,05,233)\end{array}$ & sig. t & R & $\mathrm{R}^{2}$ & F-cal & $\begin{array}{l}\text { F-tab } \\
(0.05,1,232)\end{array}$ & sig f \\
\hline Constant & 0.745 & 4.7 & 1.96 & 0.000 & \multirow{2}{*}{0.776} & 0.602 & 350.7 & 3.84 & 0.000 \\
TSP & 0.821 & 18.7 & & 0.000 & & \\
\hline
\end{tabular}

Dependent Variable; Marketing Performance

Source: SPSS 17.0 Output (based on 2012 field survey data)

$$
M P=\alpha_{o}+\alpha_{1} T S P+U_{l}
$$

$\mathrm{MP}=0.745+0.821 \mathrm{TSP}, \mathrm{t}-$ values in bracket (4.7) (18.7).

Table 1 shows that the Pearson's correlation coefficient is 0.776 . This coefficient is high indicating that a strong correlation exists between the Trade Sales Promotion and Marketing Performance. The Coefficient of Determination $\left(\mathrm{R}^{2}\right)$ is $=0.602$. This implies that a $60.2 \%$ variation in Marketing Performance is explained by variations in Trade Sales Promotion. The remaining 39.8\% is explained by other variables not included in the model. The F-calculated of 350.7 had a corresponding significant f-value of 0.000 . The researcher therefore concludes a good model utility. Conventionally F-cal is $=1350$; which is $>$ F-tab $(0.05,1,232)=3.84$. Hence the above conclusion of a good model utility is upheld. This model is contained in 3.5 of this study and is the linear model specified and found to adequately explain the objectives of the study.

The test of significance conducted as shown in the same table indicates that; Trade Sales Promotion had a calculated t-value of 18.728 and a corresponding significant/probability Value (PV) of 0.000. The PV is less than 0.05 level of significance; therefore the researcher concludes that Trade Sales Promotion is significant in determining the level of Marketing Performance. Conventionally, $\mathrm{t}$-calculated is $=18.728$ and is $>\mathrm{t}$-tabulated $(0.05,233)$ is $=1.96$ Hence the researcher upholds the above decision and concludes that Trade Sales Promotion significantly affects Marketing performance. 
Table 2. The effects of trade contest, trade fair and trade allowance on sales turnover

\begin{tabular}{|c|c|c|c|c|c|c|c|c|c|}
\hline \multirow[b]{2}{*}{ Variables } & \multirow[b]{2}{*}{ Coef. } & \multirow[b]{2}{*}{ t-cal } & \multicolumn{2}{|l|}{ t-tab } & \multirow[b]{2}{*}{$\mathrm{R}$} & \multirow[b]{2}{*}{$\mathrm{R}^{2}$} & \multirow[b]{2}{*}{ F-cal } & \multicolumn{2}{|l|}{ F-tab } \\
\hline & & & $(0,05,233)$ & sig. $t$ & & & & $(0.05,1,232)$ & $\operatorname{sig} \mathrm{f}$ \\
\hline Constant & 0.27 & 1.21 & \multirow{4}{*}{1.96} & 0.229 & \multirow{4}{*}{0.793} & \multirow{4}{*}{0.629} & \multirow{4}{*}{130.2} & \multirow{4}{*}{3.84} & \multirow{4}{*}{0.000} \\
\hline $\mathrm{TC}$ & 0.05 & 0.93 & & 0.354 & & & & & \\
\hline TA & 1.06 & 16.42 & & 0.000 & & & & & \\
\hline TF & 0.04 & 1.25 & & 0.212 & & & & & \\
\hline
\end{tabular}

Dependent Variable; Sales Turnover

Source: SPSS 17.0 Output (based on 2012 field survey data)

$$
S T O=\beta_{o}+\beta_{1} T C+\beta_{2} T A+\beta_{3} T F+U_{l}
$$

$\mathrm{STO}=0.27+0.05 \mathrm{TC}+1.06 \mathrm{TA}+0.04 \mathrm{TF}$; t-values in bracket (1.21) (0.93) (16.42) (1.25).

Table 2 indicates that the multiple Pearson's correlation coefficient is 0.793 . This coefficient is high indicating that a strong correlation exists between the dimensions of Trade Sales Promotion (Trade Contest, Trade fair, Trade allowance) and Sales Turnover

The Coefficient of Determination $\left(\mathrm{R}^{2}\right)$ is $=0.629$. This implies that a $62.9 \%$ variation in Sales Turnover is explained by variations in Trade Contest, Trade Fair and Trade Allowance. The remaining 37.1\% is explained by other variables not included in the model but also affected the market.

The F-calculated of 130.2 had a corresponding significant f-value of 0.000 ; so the researcher therefore concludes a good model utility. Conventionally F-cal is $=130.2$. This value is greater than F-tab $(0.05,1,232)$ is $=3.84$; making the model useful. Similarly the test of significance conducted shows that; Trade Contest is not significant in affecting the level of sales Turnover, $\left(\mathrm{t}\right.$-cal $=0.929<\mathrm{t}$-tab ${ }_{(0.05,233)}=1.96, \mathrm{PV}$ is $=0.354$; which is greater than $(0.05)$

Trade Fair is not significant in affecting the level of sales Turnover, (t-calculated is $=1.25<\mathrm{t}$-tab ${ }_{(0.05,233)}=1.96$, $\mathrm{PV}$ is $=0.212$; which is greater than 0.05) and Trade Allowance is significant in affecting the level of sales Turnover, ( $\mathrm{t}$-cal is $=16.42$ which is $>\mathrm{t}$-tab $(0.05,233)=1.96, \mathrm{PV}$ is $=0.000$ is less than 0.05 )

Table 3. The effects of trade contest, trade fair and trade allowance on market share

\begin{tabular}{|c|c|c|c|c|c|c|c|c|c|}
\hline & & & t-tab & & & & & F-tab & \\
\hline Variables & Coef. & t-cal & $(0,05,233)$ & sig. $t$ & $\mathrm{R}$ & $\mathrm{R}^{2}$ & F-cal & $(0.05,1,232)$ & $\operatorname{sig} \mathrm{f}$ \\
\hline Constant & 0.49 & 2.23 & \multirow{4}{*}{1.96} & 0.229 & \multirow{4}{*}{0.717} & \multirow{4}{*}{0.514} & \multirow{4}{*}{81.15} & \multirow{4}{*}{3.84} & \multirow{4}{*}{0.000} \\
\hline $\mathrm{TC}$ & 0.03 & 0.70 & & 0.487 & & & & & \\
\hline TA & 0.81 & 12.98 & & 0.000 & & & & & \\
\hline TF & 0.04 & 1.53 & & 0.129 & & & & & \\
\hline
\end{tabular}

Dependent Variable; Market Share

Source: SPSS 17.0 Output (based on 2012 field survey data)

$$
M S=\mu_{o}+\mu_{1} T C+\mu_{2} T A+\mu_{3} T F+U_{1}
$$

$\mathrm{MS}=0.49+0.03 \mathrm{TC}+0.81 \mathrm{TA}+0.04 \mathrm{TF}$, t-values in bracket (2.23)(0.70) (12.98) (1.53).

Table 3 reveals that the multiple Pearson's correlation coefficient is 0.717 . This coefficient is high indicating that a strong correlation exists between the dimensions of Trade Sales Promotion (Trade contest, trade fair and trade allowance) and Market Share. The Coefficient of Determination $\left(\mathrm{R}^{2}\right)$ is $=0.514$. This implies that a $51.4 \%$ variation in Market share is explained by variations in Trade Contest, Trade Fair and Trade Allowance. The remaining $48.6 \%$ is explained by other variables not included in the model. The F-calculated of 81.15 had a corresponding significant f-value of 0.000 ; the researcher thus concludes a good model utility. Conventionally F-cal $=81.15$ is greater than F-tab ${ }_{(0.05,1,232)}=3.84$; and is considered a useful model. Equally the test of significance conducted above shows that; Trade Contest does not significantly affect the level of Market Share $\left(\mathrm{t}-\mathrm{cal}\right.$ is $=0.696<\mathrm{t}-\mathrm{tab}_{(0.05,233)}=1.96, \mathrm{PV}=0.487$ and is $\left.>0.05\right)$ Trade Fair does not significantly affect the level of Market Share, ( $\mathrm{t}$-cal is $=1.53<\mathrm{t}-\mathrm{tab}_{(0.05,233)}=1.96, \mathrm{PV}$ is $=0.212$ which is $>0.05$ ) while Trade Allowance significantly affect the level of Market Share $(\mathrm{t}-\mathrm{cal}=12.98>\mathrm{t}$-tab $(0.05,233)=1.96, \mathrm{PV}$ is $=0.000$ which is $<0.05)$. 
Table 4. The effects of trade contest trade fair and trade allowance on profitability

\begin{tabular}{|c|c|c|c|c|c|c|c|c|c|}
\hline \multirow[b]{2}{*}{ Variables } & \multirow[b]{2}{*}{ Coef. } & \multirow[b]{2}{*}{ t-cal } & \multicolumn{2}{|l|}{ t-tab } & \multirow[b]{2}{*}{$\mathrm{R}$} & \multirow[b]{2}{*}{$\mathrm{R}^{2}$} & \multirow[b]{2}{*}{ F-cal } & \multicolumn{2}{|l|}{ F-tab } \\
\hline & & & $(0,05,233)$ & sig. $\mathrm{t}$ & & & & $(0.05,1,232)$ & $\operatorname{sig} \mathrm{f}$ \\
\hline Constant & 0.82 & 4.65 & \multirow{4}{*}{1.96} & 0.000 & \multirow{4}{*}{0.755} & \multirow{4}{*}{0.569} & \multirow{4}{*}{1015} & \multirow{4}{*}{3.84} & \multirow{4}{*}{0.000} \\
\hline $\mathrm{TC}$ & 0.12 & 2.69 & & 0.006 & & & & & \\
\hline TA & 0.68 & 13.35 & & 0.000 & & & & & \\
\hline $\mathrm{TF}$ & 0.04 & 1.85 & & 0.065 & & & & & \\
\hline
\end{tabular}

Dependent Variable; Profitability

Source: SPSS 17.0 Output (based on 2012 field survey data)

$$
\operatorname{Pr}={ }_{o}{ }_{1} T C+{ }_{2} T F+{ }_{3} T A+U_{1}
$$

$\operatorname{Pr}=082+0.12 \mathrm{TC}+0.04 \mathrm{TF}+0.04 \mathrm{TA}$, t-values in bracket (4.67) (2.69) (13.35) (1.85)

Table 4 affirms that the multiple Pearson's correlation coefficient is 0.755 . This value is high indicating that a strong correlation exists between the dimensions of Trade Sales Promotion (Trade contest, Trade fair and Trade allowance) and Profitability. The Coefficient of Determination $\left(\mathrm{R}^{2}\right)$ is $=0.564$. This implies that a $56.4 \%$ variation in Profitability is explained by variations in Trade Contest, Trade Fair and Trade Allowance. The remaining $48.6 \%$ is explained by other variables not included in the model. The F-calculated of 101.38 had a corresponding significant f-value of 0.000 ; hence the researcher concludes a good model utility. Conventionally F-cal is $=101.38$ is $>$ F-tab $(0.05,1,232)=3.84$ thus making the model useful. The test of significance conducted also shows that; Trade Contest had significant effect on Profitability (t-cal $=2.69>\mathrm{t}$-tab $(0.05,233)=1.96, \mathrm{PV}$ is $=$ 0.006; which is $>0.05$ ). Trade Fair does not significantly affect Profitability (t-cal is $=1.85<\mathrm{t}$-tab $(0.05,233)=1.96$, $\mathrm{PV}$ is $=0.212>0.05)$ and; Trade Allowance significantly affects Profitability ( $\mathrm{t}$-cal is $=13.35>\mathrm{t}$-tab ${ }_{(0.05,233)}=$ $1.96, \mathrm{PV}=0.000<0.05)$ The analyses of the regression analyses or test of effects conducted above are further summarized: in table 5 overleaf:

Table 5. The summary of result on regression analysis (test of effects)

\begin{tabular}{|c|c|c|c|c|c|}
\hline $\mathbf{s} / \mathbf{n}$ & Effects & t-cal & Direction & $\begin{array}{l}\text { Sig. } \\
\text { value }\end{array}$ & Conclusion \\
\hline 1 & $\begin{array}{l}\text { Effects of Trade Contest on Sales } \\
\text { Turnover }\end{array}$ & 0.93 & $+\mathrm{ve}$ & 0.354 & Insignificant \\
\hline 2 & $\begin{array}{l}\text { Effects of Trade Allowance on Sales } \\
\text { Turnover }\end{array}$ & 16.42 & + ve & 0.000 & Significant \\
\hline 3 & Effects of Trade Fair on Sales Turnover & 1.25 & + ve & 0.212 & Insignificant \\
\hline 4 & $\begin{array}{l}\text { Effects of Trade Contest on Market } \\
\text { Share }\end{array}$ & 0.70 & $+\mathrm{ve}$ & 0.487 & Insignificant \\
\hline 5 & $\begin{array}{l}\text { Effects of Trade Allowance on Market } \\
\text { Share }\end{array}$ & 12.98 & + ve & 0.000 & Significant \\
\hline 6 & Effects of Trade Fair on Market Share & 1.53 & $+\mathrm{ve}$ & 0.129 & Insignificant \\
\hline 7 & Effects of Trade Contest on Profitability & 2.69 & + ve & 0.000 & Significant \\
\hline 8 & $\begin{array}{l}\text { Effects of Trade Allowance on } \\
\text { Profitability }\end{array}$ & 13.35 & $+\mathrm{ve}$ & 0.000 & Significant \\
\hline 9 & Effects of Trade Fair on Profitability & 1.85 & $+\mathrm{ve}$ & 0.065 & Insignificant \\
\hline
\end{tabular}

Source: SPSS 17.0 out-put based on field survey 2012.

\section{Conclusions}

The soft drink manufacturing firms and channel members constitute the bedrock of the nation's economic growth and derive enormous contributions from optimal utilization of trade sales promotion strategies to market their products. In view of this, the following conclusions are drawn from the study:

1) Trade sales promotion strategies are in use, but not optimal (fully utilized) in the soft drink firms in Nigeria.

2) Improvements are required in trade promotion strategies to achieve optimal or superior marketing performance. 
3) Optimal utilization of trade promotion strategies promises better pay-off in form of sales turnover, market share dominance and profitability. This supports the works of Adebisi and Bayode, (2011)

4) Full utilization of trade promotion strategies affects marketing performance. It enhances sales turnover, increased market share and profitability.

5) The marketing performance of the organizations is satisfactory but equally below optimum; improvement is needed in their marketing performance.

6) Optimal utilization of trade sales promotion strategies by the soft drink firms in Nigeria, affects their marketing performance. All the accepted alternative hypotheses attest to this conclusion.

7) These hypotheses provided empirical evidence that the more the trade sales promotion strategies are utilized, the higher the marketing performance of these firms.

8) The rationale for trade fair seems to be weak and contradicts the works of Betis-Outland, et al.,2012; Hansen, 1999), but cross validates those of Hansen,(1996); Martyka, (1999)

9) Trade allowance and trade contest strategies are better, more rewarding and more direct determinants of marketing performance than trade fair.

10) Identifying the required trade promotion strategy, identifying the one in use, and determining trade promotion gap lead to sales turnover and higher market share.

11) The trade contest elements that affect marketing performance include those targeting wholesalers and retailers, rank and file of sales people and contest among brokers.

12) Trade allowance affects marketing performance of the firms. The elements of trade allowance - special incentives, discounts, rebates, off-invoice allowance, drop- ship allowance and exit fees significantly affect sales turnover, market share and profitability.

13) Trade fair does not create much impact on marketing performance of the soft drink firms in Nigeria.

\section{Recomendations}

1) The soft drink firms in Nigeria should adopt the activities involved in trade allowances and trade contests to enable them achieve optimal marketing performance.

2) Contests should be extended to distributors, retailers, agents and the generality of sales people in the firms.

3) The soft drinks firm in Nigeria should consider the trade promotion strategies that must be analyzed and evaluated from time to time, such that they can respond to the ever increasing demands of the industry.

4) Management of the soft drinks manufacturing firm should use their size structure to optimize the effect of trade sales promotion strategies on marketing performance.

5) Steps should be taken to improve the sub-optimal contribution of trade fair in order to achieve superior marketing performance contribution in this area.

6) The soft drinks firm should partner to organize and participate in trade shows from time to time, and not to wait for government to plan for them.

\section{Implications for Marketing Managers}

The soft drink firms in Nigeria like other fast moving consumer goods industries (FMCGs) are constantly striving to achieve superior marketing performance. And the Nigerian business environment offers viable untapped opportunities due to its tropical climate, large population for better patronage, and opportunities for superior marketing performance, which only firms with sound trade promotion strategies can take advantage of. Therefore, the study serves as a guide to better understanding of the relationships between trade sales promotion strategy management and marketing performance of the soft drink companies in Nigeria. Practitioners can derive the appropriate mix of strategies by examining their industry context and their firm's organizational processes in tandem. The major determinants of marketing performance are trade contest and trade allowance. In other words, marketing performance targeting sales turnover, market share and profitability, could be substantially enhanced through trade allowances and trade contests. Therefore emphasis on the activities that make up trade allowance and trade contest, all things being equal, would most likely lead a firm to achieving superior marketing performance in the soft drinks firm in Nigeria. Also rewarding is the firm's size structure and not necessarily age that moderates the influence of trade sales promotion strategies on marketing performance. 


\section{Suggestions for Further Studies}

From our empirical research perspective, the current work presents a number of opportunities for further study:

1) Further research to test trade promotion strategies can be carried out in other fast moving consumer goods industries (FMCGs), industrial, pharmaceutical, banking and telecommunication firms that are now flourishing in our country.

2) Further studies can extend and refine the measurement scheme presented in this study as part of an ever-extending process of empirical investigation.

3) Further studies can equally investigate the various predictors of marketing performance which may vary depending on the contextual variables.

4) Finally, further studies are required to replicate our research with better statistical approach and larger sample size.

\section{References}

Abraham, M., \& Lodish, L. M. (1990). Getting the Most out of Advertising and Promotion. Harvard Business Review, 68, 50-60.

Adebisi, S. A., \& Babatunde, O. (2011). Strategic Influence of Promotional Mix on Organization Sales Turnover in the face of Strong Competition. Business Intelligence Journal, 2, 1-14.

Amue, G. J. (2009). E- Commerce Capabilities Development and Corporate Marketing Performance in Nigeria Aviation Industry. Ph.D thesis, University of Port-Harcourt, Choba- Port- Harcourt.

Ante, U. (1989). Want shelf space at the supermarket? Business week, 7, 60-61.

Armstrong, J. S., \& Callopy, F. (1996). Competitor Orientation Effects of Objectives and Information on managerial Decision and Profitability: Journal of marketing Research, 23, 188-199. http://dx.doi.org/10.2307/3152146

Armstrong, J. S., \& Greene, K. C. (2007). Competitor-Oriented Objectives, The myth of market share. International journal of Business, 1, 116-134.

Avlonitis, G. J., \& Panagopulos, N. G. (2006). Role Stress, Attitudes, and Job Outcomes in Business-toBusiness Selling: Does the Type of Selling Situation Matter? Journal of Personal Selling and Sales Management, 1, 67-77.

Ayatunji, G., Ojo, O. I., \& Bamber, D. (2009). An exploratory study of students' consumption of non-alcoholic beverages in Nigeria; a qualitative perspective. Nutrition and food science journal, 39, 609-618. http://dx.doi.org/10.1108/00346650911002931

Bell, D. R. (2002). The changing channel; A better way to do trade promotions. M.T. Sloan Management Review, 2, 42-50.

Beltramini, R. F., \& Kenneth, R. E. (1998). Sales person motivation to perform and job satisfaction: A sales context participant perspective. Journal of Personal Selling and Sales Management, 8, 35-42.

Bemmaor, A. C., \& Mouchoux, D. (1991). Measuring the Short term Effect of In-store Promotion and Retail Advertising on Brand Sales, A Factorial Experiment. Journal of Marketing Research, 28, 202-214. http://dx.doi.org/10.2307/3172808

Benezra, K. (2001). Branding the Web Chief. Chief Executive, 1, 30-34.

Berry, J. (1992). Diverting. Adweeks' Marketing, 18, 20-25.

Betis-Outland, H., Johnston, W. F., \& Wilson, R. D. (2012). Using trade show information to enhance company success; An empirical investigation. Journal of Business and Industrial Marketing, 27, 384-391.

Bhak, B. H., \& Gort, M. (1993). Decomposing learning by doing in new plants. Journal of Political Economy, $101,1043-1075$.

Blakkan, R. (1983). Savoury Deals Tempt Hungry Retailers. Adverting Age, 7, 11-15.

Blattberg \& Levin. (1987). Modeling the effectiveness and profitability of trade promotions. Marketing Science Journal, 6, 125-127. 
Bloom, P. N., Gudlac, G. T., \& Canon, P. J. (2000). Slotting allowances and Fees: Schools of thoughts and views of practicing managers. Journal of Marketing, 64, 92-108. http://dx.doi.org/10.1509/jmkg.64.2.92.18002

Blyte, J. (2000). Objectives and Measures at UK Trade Exhibitions. Journal of Marketing Management, 16, 203-222. http://dx.doi.org/10.1362/026725700785100488

Bonoma, T. V. (1989). Marketing Performance; What Do You Expect? Harvard Business Review, 67, 44-48.

Brown, C., Hamilton, J., \& Medroff, J. (1990). Employers Large and Small. Cambridge: Harvard University Press.

Buss, D. D. (1996). Cashing in on Trade Shows. Nations Business Journal, 10, 21-30.

Buyline Report. (2008). Marketing Performance Measurement; Target areas where marketers want to improve and how they measure up. Retrieved from http://www.buineresearch.com

Buzzeli, R. D., Quelch, J. A., \& Salmon, W. J. (1990). The Costly Bargain of Trade Promotion. Harvard Business Review, 68, 145-150.

Chun, W. L. (2002). Sales Promotions as Strategic Communication; the case of Singapore. Journal of Product and Brand Management, 2, 103-135.

Churchill, G. A., \& Peter, J. P. (1998). Marketing: Creating Values for customers. Boston: McGraw-Hill.

Clark, B. H. (1999). Marketing Performance Measures; History and Interrelationships. Journal of Marketing Management, 15, 711-732. http://dx.doi.org/10.1362/026725799784772594

Crimmins, E. D. (1985). Dispelling The Hype of Vendor Support. Sales and Marketing Management Journal, 9 , 54-57.

Dalrymple, D. J., Cron, W. L., \& Decarlo, T. E. (2004). Sales Management. NJ: Willey.

Defloor, A., Hecke, S. V., Verhaeghe, S., Gobert, M., Darras, E., \& Grypdonck, M. (2006). The clinical Nursing competences and Their Complexity in Belgian General Hospitals. Nursing and Healthcare Management and Policy, 3, 669-678.

Dixon, A. L., Gassenheimer, J. B., \& Barr, T. F. (2003). Identifying the Lone Wolf; A Team Perspective. Journal of Personal Selling and Sales Management, 4, 205-209.

Duta, S., Berger, M., George, J., \& Rao, A. (1995). Variations in the Contractual Terms of Cooperative Advertising Contracts; An Empirical Investigation. Marketing Letters, 6, 15-18. http://dx.doi.org/10.1007/BF00994036

Eisenberger, R., \& Cameron, J. (1999). Does pay for performance increase or decrease perceived self-determination and intrinsic motivation? Journal of personality and social psychology, 77, 1026-1028. http://dx.doi.org/10.1037/0022-3514.77.5.1026

Elkin, T. (1999). Co-op Cross Roads. Advertising Age, 15, 24 \& 56.

Everett, M. (1987). Co-op Advertising and Computing. Sales and Marketing Management Journal, 5, 56-58.

Fama, E. F., \& French, K. R. (2004). New lists; Fundamentals and survival rates. Journal of Financial Economics, 73, 229-269. http://dx.doi.org/10.1016/j.jfineco.2003.04.001

Fenwick, I., \& Amine, L. (1979). Export Performance and Export Policy: Evidence from UK Clothing Industry. Journal of the Operational Research Society, 3, 747-754.

Gopalakrishna, S., \& Lilien, L. (1995). A Three Stage Model of Industrial Trade Show Performance. Marketing science journal, 14, 22-42. http://dx.doi.org/10.1287/mksc.14.1.22

Gopalakrishna, S., Lilien, L., Williams, J., \& Sequeira, I. K. (1995). Do Trade Shows pay off? Journal of marketing, 5, 75-83. http://dx.doi.org/10.2307/1252121

Greyser, S. A., \& Young, R. J. (1983). Follow 11 Guidelines to Strategically Manage Co-op Advertising Program. Marketing News, 16, 5-10.

Hansen, K. (1996). The dual motives of participants at international trade shows; An empirical investigation of exhibitors and visitors with selling motives. International Marketing Review, 2, 39-53. http://dx.doi.org/10.2307/1252121 
Hansen, K. (1999). Trade show performance; A conceptual framework and its implications for future research. Academy of science review.

Hofstrand, D. (2006). Understanding profitability. Ag Marketing Resource Centre; Iowa State University.

Hoyt, C. W. (1996). The Retailers and Suppliers are still miles apart. Promo Journal, 2, 49-51.

Hoyt, C. W. (1997). The slotting weevil. Promo Journal, 68, 64-68.

Huber, G. P., \& Power, D. J. (1986). Retrospective Reports of strategic-Level Managers; Guidelines for Increasing Their Accuracy. Strategic Management Journal, 2, 171-180.

Ikem, V. (2011). Nigeria is becoming one hell of a casino. TMKG Publishing Limited.

Jackson, D. W., Schlacter, J. L., \& Wolfe, W. G. (1995). Examining the basis utilized for evaluating sales peoples' performance. Journal of Personal Selling and Sales Management, 4, 65-66.

Jain, S. C. (1997). Marketing Planning and Strategic Management. New York: McGraw-Hill Publishing Co.

Johnston, M. W., \& Marshall, G. W. (2003). Churchill, Ford and Walker's. Sales force Management Journal, 7, 369-402.

Johnston, M. W., \& Marshall, G. W. (2005). Sales Force Management. Boston: Mcgraw-Hill.

Jolson, M. A. (1999). When Sales People Fail, Assessing Blame. Industrial Marketing Management Journal, 1, 19-26. http://dx.doi.org/10.1016/S0019-8501(98)00019-4

Kay, J. S. (1983). Foundations of Corporate Success; How business strategies add value. Oxford: Oxford University Press.

Keon, W. J., \& Raju, J. S. (1991). Effects of price promotion on Variety -seeking and Reinforcement Behaviour. Marketing science journal, 10, 1-3.

Kerin, R. A., \& Cron, W. L. (1987). Assessing trade show functions and performance. Journal of Marketing, 51, 88-100. http://dx.doi.org/10.2307/1251649

Kokkinaki, F., \& Ambler, T. (1999). Marketing Performance Assessment; An Exploratory Investigation into Current Practice and the Role of Firm Orientation. Working Paper, Marketing Science Institute, No.99-114.

Lal, R., \& Kopp, P. J. (1990). Manufacturer trade deals and retail price promotions. Journal of Marketing, 27, 428-444. http://dx.doi.org/10.2307/3172628

Largo, F. L. (1998). Cox Direct $20^{\text {th }}$ Annual Survey of Promotional Activities. Survey Journal, 50, 65-70.

Liesse, J. (1990). Kodak Branch Calls Retreat in the Battery War. Advertising age, 3, 69.

Mahajan, G. M., \& Muller, E. (1997). Assessing the Relationship between user-based market share for pirated soft ware brands in competitive markets. Technological forecasting and social change journal, 2, 131-144.

Manning, K. C. (1994). Development of A Theory of Retailer Response to Manufacturers Everyday Low Cost Program. Ph.D dissertation, University of South Carolina.

Martyka, J. (1999). Sports trade shows shrink: The Business Journal of the twin cities, 13, 10-17.

Mcconnel, C. R., \& Brue, S. L. (1990). Economics; Principles, Problems, and Policies. New-York: Mcgraw-Hill Publishing Co.

Murphy, W. H., \& Dacin, P. A. (1998). Sales Contest, a Research Agenda. The Journal of Personal Selling and Sales Management, 1, 1-16.

Narasimhan, C. (1989). Managerial perspectives on trade and consumer promotions. Marketing Letters, 1, 239-251. http://dx.doi.org/10.1007/BF00640801

Narasimhan, C. (1990). Managerial Perspectives on Consumer promotions. Journal of marketing research, 54, $54-424$.

Narasimhan, C., Neslin, S. A., \& Sen, S. K. (1996). Promotional elasticities and category characteristics. Journal of Marketing Research, 35, 17-30.

Neff, J. (1995). Diaper Battle Puts EDLP on Injured List. Advertising Age, 14, 35-36.

Nielsen, N. H. (1992). Category management. Marketing Research Journal, 4, 112-121. 
Nnabuife, K. E. (2005). Industrial Democracy in Nigeria Organizations; A Comparative Analysis of selected Banks and Oil Companies. An Unpublished Ph.d Dissertation, Faculty of Management Sciences, University of Port Harcourt.

Nwielaghi, B. M. (2003). Trade sales promotion strategies and marketing performance in the soft drink industries in Nigeria. A Ph.d thesis yet defended, University of Port-Harcourt.

Ogon, B. Y. (2007). Strategic Information Systems Planning in the Nigeria Banking Sector. A Ph.D Dissertation, Rivers State University of Science and Technology, Port Harcourt.

Ohmae, K. (1985). Triad Power: The coming shape of Global Competition. New York: Free press.

Prahalad, C. K., \& Hamel, G. (1990). The Core Competence of the Corporation. Harvard Business Review, 3 , 79-91.

Rig, C. (1990). Hard times means Growth for Co-op Ads'. Advertising Age, 4, 24.

Robson, I. (2005). Implementing a Performance Measurement Capable of creating a Culture of High Performance. International Journal of Productivity and Performanceumar Management, 1\&2, 137-145. http://dx.doi.org/10.1108/17410400510576621

Rumelt, R. P., \& Wensley, R. C. (1981). In search of the Market Share Effect. Academy of Management Proceedings, 41, 2-6. http://dx.doi.org/10.5465/AMBPP.1981.4976488

Sekaran, U. (2003). Research Methods for Business. New York: John Wiley and Sons.

Sellers, P. (1992). The Dumbest Marketing Ploy. Fortune Journal, 5, 88-95.

Tienowitz, I. (1999). Senators berate Industry Abuse of slotting fees. Advertising Age, 20, 3 \& 66.

Trade Show Bureau. (1994). A Guide to the US Exposition Industry. DENVER, Co: Trade show Bureau Resource Centre.

Uzor, B. (2011). Poor Internet service persists, telecoms reluctant to share fibre infrastructure. Business Day, 9 , 12-14.

Wildt, A. R., James, D. P., \& Clyde, E. H. (1987). Assessing the impact of sales force contests; An application. Journal of Business Research, 2, 145-155. http://dx.doi.org/10.1016/0148-2963(84)90045-6

Wilkie, W. L., Desrochers, D. M., \& Gundlac, G. T. (2002). The case of slotting fees. Journal of Marketing and Public Policy, 2, 275-288. http://dx.doi.org/10.1509/jppm.21.2.275.17591

Zebobipi, I. (2007). Worker competence Management and corporate productivity performance. A Ph.D Dissertation, Rivers state University of Science and Technology, Port-Harcourt.

\section{Copyrights}

Copyright for this article is retained by the author(s), with first publication rights granted to the journal.

This is an open-access article distributed under the terms and conditions of the Creative Commons Attribution license (http://creativecommons.org/licenses/by/3.0/). 